\title{
IMPLEMENTASI SISTEM ACTIVITY BASED COSTING TERHADAP PERHITUNGAN HARGA POKOK PRODUK (Studi Kasus pada The Redwood City Plan of Crimson Components Company)

\author{
Septi Wifasari \\ Universitas Pamulang \\ Dosen00335@unpam.ac.id
}

\begin{abstract}
With the Activity Based Costing (ABC) system, it will improve the existing deficiencies in the conventional system in terms of as a basis for managers in decision making. Many companies can improve planning, product costing, operational controls and management controls by using activity analysis to develop a detailed picture of the activity providing the basis for Activity Based Costing. Activity Based Costing is used to improve the accuracy of cost analysis by improving the way cost tracking to cost objects. Activity Based Costing is used for different cost objects of individual products, interrelated product groups and individual customers. This system is useful when company ops is complex with many product types and manufacturing processes.
\end{abstract} Keywords: Activity Based Costing, conventional system, cost object, product
cost, cost of product

\section{PENDAHULUAN}

Dalam era globalisasi sekarang ini setiap perusahaan akan dihadapkan pada lingkungan yang penuh dengan persaingan, karena itu perusahaan tersebut sangat membutuhkan informasi yang akurat dan berkualitas yang digunakan untuk pengambilan keputusan dalam hal mengenai proses produksi dan sumber sumber daya yang di konsumsinya, yang berorientasi pada penggunaan teknologi maju. Khususnya informasi yang dibutuhkan dalam perusahaan manufaktur adalah informasi manajemen biaya karena kebutuhan yang mendesak untuk mengelola biaya produksi.

Strategi dalam menerapkan sistem biaya yang tepat dapat menunjang keberhasilan perusahaan dalam mengantisipasi perubahan - perubahan yang 
terjadi yaitu : produk dan proses produksi yang dirancang untuk mengakomodasikan perubahan - perubahan yang diharapkan dalam permintaan pelanggan. Fleksibilitas merupakan hal penting dalam kemampuan perusahaan untuk membuat perubahan - perubahan tenrtang kecepatan pasar dan pemanufakturan yang tepat.

The Redwood City Plan of Crimson Compoonents Company merupakan perusahaan manufaktur yang memproduksi 2 tipe rotartis yaitu R 361 dan R 572 untuk engine automobile. Perusahaan ini menghadapi krisis ketika meningkatkan jenis dari volume dan banyak pelanggan yang meminta pelayanan khusus.

Dalam penentuan harga pokok produk yang lama pada perusahaan menggunakan biaya tenaga langsung berdasarkan biaya sebagai cost driver untuk semua baiaya non bahan, tanpa memperhitungkan cost driver yang sesungguhnya. Akibat dari penggunaan biaya tenaga kerja langsung adalah distorsi bauiaya yang sangat signifinakan produk dengan biaya tenaga kerja langsung lebih besar, harga pokoknya ditentukan terlalu tinggi, sedangkan produk dengan biaya tenaga kerja langsung lebih sedikit, harga pokoknya ditentukan terlalu rendah. Manajer tidak percaya dengan prediksi biaya produk yang menggunakan sistem lama berdasarkan tenaga kerja langsung ini.

Oleh karena itu perusahaan manufaktur untuk megimplementasikan sistem Activity Based Costing untuk menelusuri biaya produk berdasarkan aktivitas yang dikonsumsi oleh produk. Sistem Activity Based Costing memberikan informasi yang berguna bagi manajer dalam membuat suatu keputusan tentang penentuan harga jual dan keputusan komposisi produk dan tujuan pengendalian laba dan biaya. Disamping itu, Activity Based Costing juga terus membantu karyawan untuk mengidentifikasi peluang untuk perbaikan pabrik dan meningkatkan proses kualitas total.

Berdasarkan uraian kasus diatas, amak rumusan permasalahan yang akan dibahas sebagai beikut :

1. Bagaimana perhitungan biaya produk per unit dengan menggunakan sistem konvensional dari masing - masing jenis produk 
2. Bagaimana perhitungan biaya produk per unit dengan menggunakan sistem Activity Based Costing dari masing-masing jenis produk

3. Jelaskan mengenai perbandingan analisis profitabilitas produk dari kedua sistem biaya accounting

4. Apa yang harus dilakukan manajer perushaan untuk menghindari kegagalan dalam implementasi sistem baru

5. Jelaskan apa yang menjadi pertimbangan manajer perusahaan dalam implementasi sistem baru Activity Based Costing

\section{TELAAH LITERATUR DAN PENGEMBANGAN HIPOTESIS}

\section{Pengertian Harga Pokok Produk}

Seiring dengan adanya perkembangan teknologi produksi tersebut, perusahaan manufaktur didorong untuk melakukan perubahan di dalam proses produksi, memperbaiki penentapan harga jual produk, desain produk, dan cara pendistribusian produk tersebut. Perkembangan ini karena adanya tuntutan manajemen perusahaan untuk lebih efektif dalam menentukan harga pokok produknya, sehingga dapat bersaing dengan perusahaan - perusahaan lain yang sejenis. Dalam menetapkan harga pokok produk yang tepat dan optimal, maka diperlukan ketentuan mengenai baiay harga pokok produksi, dengan perhitungan harga pokok produksi yang akurat yang menguntungkan perusahaan.

Definisi harga pokok menurut Harnanto (1992 : 204) adalah sebagai berikut : “ Harga pkok produksi adalah biaya produksi yang melekat pada setiap unit produknya “

Harga pokok produk merupakan biaya dari suatu produk, amaka perhitungan produk ditujukan untuk mengetahui pengorbanan-pengorbanan yang terjadi dalam menghasilkan suatu produk. Informasi harga produk tidak hanya diperlukan untuk penilaian efisiensi operasi perusahaan, tetapi juga untuk digunakan sebagai dasar penilaian persediaan dan penentuan hrag pokok penjualannya dalam menentukan laba rugi perusahaan. 
Tujuan dari harga pokok produk adalah :

1. Penetapan harga dan penekanan pada produk

Untuk tujuan ini, biaya dari seluruh bidang value chain yang diperlukan untuk membawa produk ke konsumen seharusnya dimasukkan

2. Kontrak dengan lembaga pemerintah

Badan pemerintah seringkali memberikan petunjuk rinci mengenai unsur yang diperbolehkan dan tidak diperbolehkan dalam jumlah harga pokok produk

3. Pelaporan keuangan ektern

Berfokus pada inventoriable cost untuk pelaporan neraca dan laba rugi. Berdasarkan prinsip akuntansi yang berlaku umum, hanya biaya pabrikasi ke produk untuk pelaporan ekstern (Horngren, 1994:51)

\section{Pengertian Biaya}

Menurut Milton F. Usry dan Lawrence H. Hammer menjelaskan bahwa :

“Biaya adalah suatu nilai tukar prasyarat, pengorbanan yang dilakukan guna memperoleh manfaat. Dalam akuntansi, prasyarat/pengorbanan tersebut pada tanggal dinyatakan dengan pengurangan kas/aktiva lainnya pada saat ini/dimasa mendatang”. (Alfonsus Sirait dan Herman Wibowo, 1999, 25)

Pengertian biaya menurut Mulyadi :

“Pengorbanan sumber ekonomi (suatu sumber dikatakan ekonomis), jika memiliki sifat kelangkaan) yang diukur dalam satuan uang, yang terjadi atau kemungkinan akan terjadi untuk mencapai tujuan tertentu” (Mulyadi, 1999, 8)

\section{Klasifikasi Biaya}

Biaya dapat digolongkan dengan berbagai macam cara. Umumnya penggolongan biaya ditentukan atas dasar tujuan yang akan dicapai. Menurut Milton F. Usry dan Lawrence H. Hammer yang dialihbahasakan oleh Alfonsusu Sirait dan herman Wibowo mengklasifikasikan biaya sebagai berikut :

1. Biaya dalam hubungannya dengan produk, terdiri dari : 
a. Biaya produksi

a) Bahan langsung

Yaitu semua bahan yang berbentuk bagian integral dari barang jadi dan yang dapat dimasukkan langsung dalam kalkulasi biaya produk

b) Tenaga kerja langsung

Yaitu karyawan yang dikerahkan untuk merubah bahan-bahan langsung menjadi barang jadi. Biaya ini meliputi gaji karyawan yang dapat dibebankan pada produk tersebut

c) Biaya tidak langsung pabrik

Yaitu biaya dari bahan tidak langsung, pekerja tidak langsung, dan semua biaya pabrikasi lainnya yang tidak dapat dibebankan langsung ke produk tertentu

b. Biaya komersial

a) Biaya pemasaran

Meliputi biaya distribusi dan penjualan, dimulai pada saat biaya pabrik berakhir

b) Biaya administrasi

Meliputi biaya yang dikeluarkan dalam mengatur dan mengendalikan organisasi

2. Biaya dalam hubungannya dengan volume produksi

a. Biaya variabel, mempunyai ciri-ciri sebagai berikut :

a) Perubahan jumlah total dalam proporsi yang sama dengan perubahan volume

b) Biaya per unit relatif konstan meskipun volume berubah dalam rentang yang relevan

c) Dapat dibebankan kepada departemen operasi dengan mudah dan tepat

b. Biaya tetap, mempunyai ciri-ciri sebagai berikut :

a) Jumlah keseluruhan yang tetap dalam rentang keluaran yang relevan 
b) Penurunan biaya per unit bila volume bertambah dalam rentang yang relevan

c) Dapat dibebankan kepada departemen - departemen berdasarkan keputusan manajemen atau menurut metode alokasi biaya

c. Biaya semi variabel

Mencakup jumlah yang sebagian tetap dalam rentang keluaran yang relevan, dan bagian lainnya bervariasi sebanding dengan perubahan jumlah keluaran

3. Biaya dalam hubungannya dengan periode akuntansi, terdiri dari :

a) Biaya belanja modal

Yaitu dimaksudkan untuk menghasilkan manfaat dalam periode - periode mendatang dan dicatat sebagai aktiva

b) Pengeluaran pendapatan

Yaitu pengeluaran pendapatan yang memberi manfaat dalam periode berjalan dan dicatat sebagai biaya

4. Biaya dalam hubungannya dengan keputusan yang diusulkan, pelaksana, dan evaluasi
a. Biaya diferensial
b. Biaya marjinal
c. Biaya incremental
d. Biaya kesempatan

Sistem biaya konvensional pada perhitungan harha pokok produk

Menurut Brimson (1991:7), sistem biaya konvensional dinyatakan sebagai berikut :

“Convensional accounting system were designed for a prior era when direct and material were predominant factors of production, technology was stable, overhead activity supported the production process, and there was a limited range of production" 
Berdasarkan definisi diatas, dapat ditarik kesimpulan bahwa pada sistem biaya konvensional alokasi biaya dilakukan dengan menggunakan metode langsung (direct method) yang hanya mengalokasikan biaya departemen pendukung ke departemen produksi, dengan mengalokasikan secara langsung biaya departemen pendukung ke departemen produksi kemungkinan dapat mengakibatkan beberapa aktivitas dari departemen mendukung yang mungkin masih bermanfaat kepada departemen pendukung yang lainnya. Dalam metode konvensional ada 2 tahap yaitu :

1. Tahap pertama

Yaitu mengalokasikan biaya overhead ke pusat biaya

2. Tahap kedua

Yaitu tahap dimana biaya-biaya yang dialokasikan pada tahap pertama dibebankan ke unit produk

Menurut Mulyadi (1993:88), pengertian alokasi biaya (cost aloocation) sebagai berikut :

“Merupakan pembagian biaya tidak langsung kepada berbagai objek informasi atau suatu dasar alokasi yang lebih bersifat sembarang”

Karekteristik pembebanan biaya overhead pabrik dalam lingkungan manufaktur konvensional adalah sebagai berikut :

1. Pusat biaya yang dibentuk seringkali berupa agregat berbagai kegiatan yang tidak homogeny sehingga dasar pembebanan yang digunakan untuk membebankan biaya overhead pabrik tidak mencerminkan konsumsi biaya overhead pabrik tersebut secara cermat oleh produk yang diproduksi

2. Dasar yang digunakan untuk membebankan biaya overhead pabrik kepada produk dipusatkan biaya produksi hanya yang berkaitan dengan volume produk dalam bentuk unit produk yang diproduksi, jam tenaga kerja langsung atau jam mesin)

Ada beberapa kelebihan yang diperoleh dalam perhitungan harga pokok produk melalui sistem biaya konvensional yaitu :

1. Mudah diterapkan 
Dalam perhitungan sistem konvensional cost driver nya sedikit sehingga dalam mengalokasikan biaya overhead pabrik berdasarkan tolak ukur volume produksi, ini akan memudahkan pihak manajemen dalam melakukan perhitungan biaya produksi

2. Mudah diaudit

Aktivitas yang terjadi tidak banyak maka akan memudahkan auditor dalam melaksanakan proses auditnya

Sedangkan kelemahan dengan menggunakan sistem biaya konvensional dikarenakan :

1. Dipandang tidak cocok dengan lingkungan usaha era globalisasi

2. Lebih berorientasi pada teori organisasi klasik

3. Lebih mementingkan laba jangka pendek daripada laba jangka panjang sehingga lebih mendahulukan marketing strategi daripada manufacturing/operating strategy

4. Mengalokasikan biaya overhead berdasarkan tolak ukur volume, yang secara sistematis menyebabkan over costing pada produk yang bervolume rendah atau under costing bagi produk yang bervolume tinggi

\section{Activity Based Costing pada Perhitungan Harga Pokok Produk}

Pengertian dari Activity Based Costing menurut Hongren, Foster dan Datar (2000:140) sebagai berikut :

“ ABC systems refine costing systems by focusing on individual activities as the fundamental cost objects. ABC systems calculate the costs of individual activities and assigns costs to costs objects such as produts and services on the basis of the activities undertaken to produce each product or service” Sedangkan menurut Amin Widjadja Tunggal (2001:114) sebagai berikut :

“Activity based costing adalah suatu metodologi yang mengukur biaya dan kinerja dari aktivitas, sumber daya dan obyek biaya. Sumber daya dikonsumsikan oleh aktivitas. Kemudian aktivitas dibebankan ke objek biaya berdasarkan penggunaannya” 
Dari definisi diatas, maka tampak bahwa pendekatan sistem ABC memfokuskan pada aktivitas perusahaan dalam menghasilkan suatu produk atau jasa. Fungsi utama dari suatu aktivitas adalah mengkonversi sumber daya menjadi output (produk). Tujuan utama dari sistem ABC adalah mengalokasikan biaya ke transaksi atau aktivitas yang tepat ke produk sesuai dengan pemakaian aktivitas setiap produk.

Adapun tahap - tahap dalam merancang system Activity Based Costing ada 3 tahap utama adalah sebagai berikut :

\section{Tahap Pertama}

Adalah mengidentifikasikan biaya sumber daya dan analisis aktivitas. Biaya sumber daya adalah biaya yang dikeluarkan untuk melakukan berbagai aktivitas. Sedangkan analisis aktivitas adalah identifikasi dan deskripsi aktivitas dalam perusahaan.

2. Tahap Kedua

Adalah membebankan sumber daya ke aktivitas. Driver sumber daya digunakan untuk membebankan biaya sumber daya ke aktivitas.

3. Tahap Ketiga

Adalah membebankan biaya aktivitas ke objek biaya. Jika biaya aktivitas sudah diketahui, selanjutnya perlu untuk mengukur biaya aktivitas per unit. Hal ini dilakukan dengan cara mengukur biaya per unit untuk output yang diproduksi oleh aktivitas tersebut.

Ada beberapa keuntungan menurut para ahli yang dapat diperoleh melalui sistem Activity Based Costing yaitu

1. Membantu mengurangi distorsi yang di sebabkan oleh alokasi biaya konvensional

2. Activity Based Costing juga mamberikan pandangan yang jelas tentang bagaimana komposisi perbedaan produk dan aktivitas perusahaan yang memberi kontribusi sampai lini yang paling dasar dalam jangka panjang

Sedangkan keunggulan yang dimiliki sistem Activity Based Costing diharapkan dapat memberikan manfaat dalam memperbaiki pengambilan 
keputusan yang dilakukan manajamen untuk kegiatan produksi dan mengurangi biaya overhead. Manfaat utama dari sistem Activity Based Costing adalah sebagai berikut :

1. Menyajikan biaya produk lebih akurat dan informatif yang megarahkan kepada pengukuran profitabilitas produk yang lebih akurat dan keputusan startejik yang lebih baik tentang penentuan harga jual, lini produk, pasar dan pengeluaran modal.

2. Menyajikan pengukuran yang lebih akurat tentang biaya yang dipicu oleh adanya aktivitas

Namun sistem Activity Based Costing masih bukan merupakan sistem akuntansi biaya yang sempurna dalam perhitungan harga pokok produk, sehingga masih terdapat kelemahan - kelemahan antara lain sebagai berikut :

1. Banyak perusahaan masih menganggap biaya overhead tidak berperan dominan sehingga tidak terlau diperhitungkan

2. Memerlukan biaya yang relative tinggi, Karena harus merubah system perusahaan yang sudah lama digunakan untuk menetapkan sistem baru

3. Kompleksnya penerapan sistem Activity Based Costing dapat menyebabkan pemicu biaya yang lebih besar

Menurut sistem Activity Based Costing, aktivitas dapat digolongkan ke dalam empat kelompok yaitu :

1. Aktivitas berlevel unit Yaitu aktivitas yang dilakukan untuk memproduksi setiap satu unit produk. Contoh : pemakaian bahan, pemakaian jam kerja langsung, dan inspeksi setiap unit

2. Aktivitas berlevel batch

Yaitu aktivitas yang dilakukan untuk setiap kelompok produk. Contohnya ; setup mesin, pemesanan pembelian, dan penjadwalan produksi

3. Aktivitas berlevel product 
Yaitu aktivitas yang dilakukan untuk mendukung produksi produk yang berbeda. Contoh : biaya penelitian dan pengembangan produk, biaya perekayasaan proses

4. Aktivitas berlevel fasilitas

Yaitu aktivitas yang dilakukan untuk mendukung produksi produk secara umum. Contoh : keselamatan kerja, pemeliharaan, dan depresiasi pabrik.

\section{Perbedaan antara sistem Activity Based Costing dengan sistem biaya konvensional}

Perbedaan antara sistem Activity Based Costing dengan pendekatan sistem biaya konvensional menurut Amin (2000:26) adalah :

A. Sistem Activity Based Costing

1. Menggunakan aktivitas - aktivitas sebagai pemicu untuk menentukan berapa besar setiap produk mengkonsumsi overhead

2. Membagi konsumsi overhead ke dalam empat kategori yaitu : unit, batch, produk, dan penopang fasilitas

3. Berfokus pada biaya, mutu, dan factor waktu

4. Mempunyai kebutuhan yang jauh lebih kecil utnuk analisis varian, Karena kelompok biaya (cost pool) dan pemicu (driver) jauh lebih akurat dan jelas

5. Dalam sistem Activity Based Costing, pemicu biaya adalah pusat aktivitas atau activity center sehingga alokasi biaya adalah aktivitas yang bersangkutan

B. Sistem Konvensional

1. Mengalokasikan overhead berdasarkan satu atau dua basis alokasi yang nonrepresentatif, dengan demikian gagal menyerap konsumsi overhead yang benar menurut produk individual

2. sistem biaya konvensional membagi biaya overhead ke dalam unit dan yang lain

3. berfokus pada kinerja keuangan jangka pendek, seperti laba dengan cukup akurat 
4. Pemicu biaya terletak pada pusat biaya atau cost driver, sehingga alokasi biaya adalah dari pusat biaya ke produk adalah basis unit

Dalam perhitungannya untuk sistem konvensional dan sistem Activity Based Costing terdapat perbedaan yaitu :

1. Proses pembebanan pada Activity Based Costing ada tiga tahap yaitu :

a. Pertama, biaya ditelusuri ke driver sumber daya yang sama yang dibebankan pada pusat aktivitas (cost pool)

b. Kedua, tarif overhead pabrik dihitung untuk setiap aktivitas berdasarkan driver aktivitas tertentu

c. Ketiga, biaya overhead dibebankan ke setiap produk dengan cara mengalikan tarif overhead pabrik dengan kuantitas driver aktivitas yang dikonsumsi oleh produk

2. Proses pembebanan pada sistem konvensional perbedaannya terletak pada tahap kedua dan ketiga dimana :

a. Dalam sistem konvensional, overhead pabrik dialokasikan berdasarkan jam kerja lamgsung (JKL)

b. Dalam sistem Activity Based Costing, tarif cost driver untuk setiap cost driver aktivitas yaitu tarif aktivitas dihitung dari baiay per aktivitas dikalikan dengan konsumsi aktivitas

\section{Pengembangan Hipotesis}

Hipotesis dapat diartikan secara sederhana sebagai dugaan sementara. Hipotesis berasal dari bahasa Yunani hypo yang berarti di bawah dan thesis yang berarti pendirian, pendapat yang ditegakkan, kepastian. Jika dimaknai secara bebas, maka hipotesis berarti pendapat yang kebenarannya masih diragukan. Untuk bisa memastikan kebenaran dari pendapat tersebut, maka suatu hipotesis harus diuji atau dibuktikan kebenarannya.

Untuk membuktikan kebenaran suatu hipotesis, seorang peneliti dapat dengan sengaja menciptakan suatu gejala, yakni melalui percobaan atau 
penelitian. Jika sebuah hipotesis telah teruji kebenarannya, maka hipotesis akan disebut teori.

Dalam penelitian ada dua jenis hipotesis yang seringkali harus dibuat oleh peneliti, yakni hipotesis penelitian dan hipotesis statistik.

a. Pengujian hipotesis penelitian merujuk pada menguji apakah hipotesis tersebut betul-betul terjadi pada sampel yang diteliti atau tidak. Jika apa yang ada dalam hipotesis benar-benar terjadi, maka hipotesis penelitian terbukti, begitu pun sebaliknya. Terdapat juga tiga macam hipotesis dalam penelitian, yakni hipotesis deskriptif, hipotesis komparatif, dan hipotesis asosiatif. Masingmasing dari hipotesis ini dapat digunakan sesuai dengan bentuk variabel penelitian yang digunakan.

\section{Hipotesis Deskriptif}

Hipotesis deskripsif dapat didefinisikan sebagai dugaan atau jawaban sementara terhadap masalah deskriptif yang berhubungan dengan variabel tunggal/mandiri.

2. Hipotesis komparatif

Hipotesis komparatif dapat didefinisikan sebagai dugaan atau jawaban sementara terhadap rumusan masalah yang mempertanyakan perbandingan (komparasi) antara dua variabel penelitian.

\section{Hipotesis asosiatif}

Hipotesis asosiatif dapat didefinisikan sebagai dugaan/jawaban sementara terhadap rumusan masalah yang mempertanyakan hubungan (asosiasi) antara dua variabel penelitian.

b. pengujian hipotesis statistik berarti menguji apakah hipotesis penelitian yang telah terbukti atau tidak terbukti berdasarkan data sampel tersebut dapat diberlakukan pada populasi atau tidak.

Sehingga Hipotesis yang ditetapkan berdasarkan kajian dan telaah literatur di atas, sebagai berikut :

Ha1: Mengetahui perhitungan biaya produk per unit dengan menggunakan sistem konvesnional dari masing - masing jenis produk R 361 dan R 572 
Ha2: Mengetahui perhitungan biaya produk per unit dengan menggunakan sistem Activity Based Costing dari masing jenis produk R 361 dan R 572

Ha3: Mengetahui perbandingan analisis profitabilitas produk dari kedua sistem biaya accounting

Ha4: Mengetahui yang harus dilakukan manajer perusahaan untuk menghindari kegagalan dalam implementasi sistem baru

Ha5: Mengetahui dasar pertimbangan manajer perusahaan dalam implementasi sistem baru yaitu Activity Based Costing

\section{METODE PENELITIAN DAN PEMBAHASAN}

Maksud dari penelitian adalah untuk mendapatkan penyelesaian masalah terhadap kasus pada The Redwood City Plant of crimson Components Company dalam ketidakakuratan perhitungan harga produk per unit.

Dalam penelitian ini metode yang digunakan adalah metode analisis kuantitatif. Menurut Indriantoro \& Supomo (1999: 12), penelitian kuantitatif menitikberatkan pada pengujian teori-teori yang diukur melalui hubungan antar variabel dan analisis dengan prosedur statistik.

Adapun data penelitian didapat dari sistem akuntansi biaya konvensional yang digunakan dalam perusahaan tersebut yang membagi biaya overhead ke dalam 4 kelompok aktivitas yaitu :

Tabel 1

Biaya overhead per aktivitas

\begin{tabular}{|crc|}
\hline Cost Pool & Overhead & Alokasi \\
S1 & $\$ 1.176 .000$ & Direct labor cost \\
S2 & 1.120 .000 & Machine hours \\
P1 & 480.000 & \\
P2 & $\$ \frac{780.000}{556.000}$ & \\
& $\$ 3.5500$ & \\
\hline
\end{tabular}


a. Pool S1 meliputi biaya - biaya aktivitas jasa yang berkaitan dengan setup, produksi scheduling, administrasi, service, material handling, dan pengiriman.

b. Pool S2 meliputi biaya umum yang berkaitan dengan pemeliharaan mesin dan perbaikan, sewa, idle time, dan bahan tidak langsung untuk 2 departemen produksi yaitu : casting dan machining yang berturut - turut.

Sistem akuntansi konvensional mengalokasikan biaya umum dalam pool S1 dan S2 untuk 2 deaprtemen produksi yang menggunakan biaya tenaga kerja langsung dan jam mesin. Kemudian biaya umum yang dikumpulkan dalam Pool P1 dan P2 telah diberlakukan bagi produk atas dasar jam tenaga kerja langsung. Suatu tingkat biaya terpisah telah ditentukan untuk masing-masing 2 Departemen produksi. Tingkat upah tenaga kerja langsung adalah $\$ 15$ per jam dalam departemen casting (P1) dan $\$ 18$ per jam dalam departemen machining (P2).

\section{Tabel 2}

Direct Labor Hours (DLH)

\begin{tabular}{|l|r|r|r|}
\hline \multicolumn{1}{|c|}{ Departemen } & \multicolumn{1}{c|}{ R 361 } & \multicolumn{1}{c|}{ R 572 } & \multicolumn{1}{c|}{ Total } \\
\hline Casting (P1) & 60.000 & 20.000 & 80.000 \\
\hline Machining (P2) & 72.000 & 48.000 & 120.000 \\
\hline & $\mathbf{1 3 2 . 0 0 0}$ & $\mathbf{6 8 . 0 0 0}$ & $\mathbf{2 0 0 . 0 0 0}$ \\
\hline
\end{tabular}

Tabel 3

Machine Hours (MH)

\begin{tabular}{|l|r|r|r|}
\hline \multicolumn{1}{|c|}{ Departemen } & \multicolumn{1}{c|}{ R 361 } & R 572 & \multicolumn{1}{c|}{ Total } \\
\hline Casting (P1) & 30.000 & 10.000 & 40.000 \\
\hline Machining (P2) & 72.000 & 48.000 & 120.000 \\
\hline & $\mathbf{1 0 2 . 0 0 0}$ & $\mathbf{5 8 . 0 0 0}$ & $\mathbf{1 6 0 . 0 0 0}$ \\
\hline
\end{tabular}

Sekarang pabrik telah menetapkan suatu aktivitas mendasarkan sistem penetapan biaya. Dari table diatas menyajikan biaya aktivitas konvensional yang diusut untuk masing - masing biaya aktivitas yang baru. 


\begin{tabular}{|c|c|c|c|c|c|}
\hline \multirow{2}{*}{$\begin{array}{l}\text { Activity } \\
\text { cost driver }\end{array}$} & \multicolumn{4}{|c|}{ Old Cost Pools } & \multirow{2}{*}{ Total } \\
\hline & S1 & $\mathrm{S} 2$ & $\mathrm{P} 1$ & $\mathrm{P} 2$ & \\
\hline P1 - DLH & $\$ 120.000$ & - & $\$ 120.000$ & - & $\$ 240.000$ \\
\hline P2 - DLH & 240.000 & - & - & $\$ 120.000$ & 360.000 \\
\hline Setup Hour & 816.000 & $\$ 80.000$ & 240.000 & 540.000 & 1. 676.000 \\
\hline $\mathrm{P} 1-\mathrm{MH}$ & - & 260.000 & 120.000 & - & 380.000 \\
\hline \multirow[t]{2}{*}{$\mathrm{P} 2-\mathrm{MH}$} & - & 780.000 & - & 120.000 & 900.000 \\
\hline & \$ 1.176.000 & \$1.120.000 & $\$ 480.000$ & $\$ 780.000$ & \$ 3.556.000 \\
\hline
\end{tabular}

Susunan untuk R 572 adalah 50\% lebih kompleks daripada R 361, dimana masing-masing dari setup R 572 mengambil 1,5 kali lebih lama daripada setup R 361.

Dalam pembahasan ini akan dibahas pada kasus The Redwood City plant of Crimson Components Company, berdasarkan perumusan hipotesis adalah sebagai berikut :

Ha1: Mengetahui perhitungan biaya produk per unit dengan menggunakan sistem konvensional dari masing - masing jenis produk $\mathbf{R} 361$ dan $R$ 572

\section{Tabel 4}

Alokasi Tahap Satu

Perhitungan Harga Pokok Produk dengan Sistem Konvensional

\begin{tabular}{|lrr|}
\hline & $\begin{array}{c}\text { Departemen P1 } \\
\text { (Casting) }\end{array}$ & \multicolumn{1}{c|}{$\begin{array}{c}\text { Departemen P1 } \\
\text { (Casting) }\end{array}$} \\
\hline Biaya overhead & $\$ 480.000$ & $\$ 780.000$ \\
Alokasi dari S1** & 776.160 & 399.840 \\
Alokasi dari S2*** & $\underline{739.200}$ & $\underline{380.800}$ \\
Total overhead & 1.995 .360 & 1.560 .640 \\
DLH & 80.000 & 120.000 \\
Overhead rate per DLH & $\$ 25$ & $\$ 13$ \\
\hline
\end{tabular}




$$
\text { ** } \begin{array}{lll}
\$ 1.176 .000 \times(132.000 / 200.000) & =\$ 776.160 \\
& \$ 1.176 .000 \times(68.000 / 200,000) & =\$ 399.840 \\
* * * \quad \$ 1.120 .000 \times(132.000 / 200.000) & =\$ 739.200 \\
& \$ 1.120 .000 \times(68.000 / 200.000) & =\$ 380.000
\end{array}
$$

\begin{tabular}{|c|c|c|}
\hline Alokasi dari & & R 361 \\
\hline Departemen P1 & $(\$ 25 * 60.000)$ & $\$ 1.496 .520$ \\
\hline Departemen P2 & $(\$ 13 * 72.000)$ & $\underline{936.000}$ \\
\hline \multirow[t]{2}{*}{ Total Overhead } & & \$ 2.432.520 \\
\hline & & R 361 \\
\hline Direct Material & $(\$ 8 * 500.000)$ & $\$ 4.000 .000$ \\
\hline Direct Labor P1 & $(\$ 15 * 60.000)$ & 900.000 \\
\hline Direct Labor P2 & $(\$ 18 * 72.000)$ & 1.296 .000 \\
\hline Overhead & & $\underline{2.432 .520}$ \\
\hline Total cost & & \$ 8.628.520 \\
\hline Number of units & & 500.000 \\
\hline Unit cost & $(\$ 8.628 .520 / 500.000)$ & $\$ 17.25$ \\
\hline Alokasi dari & & R 572 \\
\hline Departemen P1 & $(\$ 25 * 20.000)$ & $\$ 498.840$ \\
\hline Departemen P2 & $(\$ 13 * 48.000)$ & $\underline{624.000}$ \\
\hline \multirow[t]{2}{*}{ Total Overhead } & & $\$ 1.122 .840$ \\
\hline & & R 572 \\
\hline Direct Material & $(\$ 10 * 400.000)$ & $\$ 4.000 .000$ \\
\hline Direct Labor P1 & $(\$ 15 * 20.000)$ & 300.000 \\
\hline Direct Labor P2 & $(\$ 18 * 48.000)$ & 864.000 \\
\hline Overhead & & $\underline{1.122 .840}$ \\
\hline
\end{tabular}

\section{Tabel 5}

Alokasi Tahap Dua

Perhitungan Harga Pokok Produk dengan Sistem Konvensional 
Ha2: Mengetahui perhitungan biaya produk per unit dengan menggunakan sistem Activity Based Costing dari masing jenis produk R 361 dan R 572

Tabel 6

Perhitungan Harga Pokok Produk per unit Sistem Activity Based Costing

\begin{tabular}{|lrr|}
\hline Cost driver & R 361 \\
\hline P1 - DLH & $\$ 240.000 *(60.000 / 80.000)$ & $\$ 180.000$ \\
P2 - DLH & $\$ 360.000 *(72.000 / 120.000)$ & 216.000 \\
Setup hours & $\$ 1.676 .000 *(2000 /(6000+2000))$ & 419.000 \\
P1 - MH & $\$ 380.000 *(30.000 / 40.000)$ & 285.000 \\
P2 - MH & $\$ 900.000 *(72.000 / 120.000)$ & $\underline{540.000}$ \\
Total overhead & $(\$ 8 * 500.000)$ & $\$ 4.000 .000$ \\
& $(\$ 15 * 60.000)$ & 900.000 \\
Direct material & $(\$ 18 * 72.000)$ & 1.296 .000 \\
Direct labor P1 & & $\mathbf{1 . 6 4 0 . 0 0 0}$ \\
Direct labor P2 & & 1.640 .000 \\
Overhead & & $\mathbf{\$ 7 . 8 3 6 . 0 0 0}$ \\
Total cost & & 500.000 \\
Number of units & & $\mathbf{\$ 1 5 . 6 7}$ \\
Unit cost & $(\$ 7.836 .000 / 500.000)$ & \\
& $\$ 360.000 *(48.000 / 120.000)$ & 144.000 \\
\hline Cost driver & & $\mathbf{R ~ 5 7 2}$ \\
\hline P1 - DLH & & \\
P2 - DLH & & \\
\hline
\end{tabular}




\begin{tabular}{|lrr|}
\hline Setup hours & $\$ 1.676 .000 *(3000 /(6000+2000))$ & 628.500 \\
P1 - MH & $\$ 380.000 *(10.000 / 40.000)$ & 95.000 \\
P2 - MH & $\$ 900.000 *(48.000 / 120.000)$ & $\underline{360.000}$ \\
Total overhead & $(\$ 10 * 400.000)$ & $\$ 4.000 .000$ \\
& $(\$ 15 * 20.000)$ & 300.000 \\
Direct material & $(\$ 18 * 48.000)$ & 864.000 \\
Direct labor P1 & & 1.287 .500 \\
Direct labor P2 & & $\mathbf{\$ 1 . 5 0 0}$ \\
Overhead & & 400.000 \\
Total cost & & $\mathbf{\$ 1 6 . 1 3}$ \\
Number of units & & \\
Unit cost & $(\$ 6.451 .500 / 500.000)$ & $\mathbf{\$ 1 0 0 0}$ \\
\hline
\end{tabular}

Ha3: Mengetahui perbandingan analisis profitabilitas produk dari kedua sistem biaya accounting

Table 7

Analisis Profitabilitas

Sistem Biaya Konvensional

\begin{tabular}{|lrr|}
\hline & & R 361 \\
\hline Number of units & $(\$ 8.628 .520 / 500.000)$ & 500.000 \\
Unit cost & $\$ 17.26$ \\
Sales price & $\$ 19-\$ 17.26)$ & $\$ 1.74$ \\
Gross margin & & R 572 \\
\hline & $(\$ 6.286 .840 / 400.000)$ & 400.000 \\
\hline Number of units & $\$ 15.72$ \\
Unit cost & $(\$ 20-\$ 15.72)$ & $\$ 20$ \\
Sales price & $\$ 4.28$ \\
Gross margin & & \\
\hline
\end{tabular}

Table 8 
Analisis Profitabilitas

Sistem Activity Based Costing

\begin{tabular}{|lrr|}
\hline & & R 361 \\
\hline Number of units & $(\$ 7.836 .000 / 500.000)$ & 500.000 \\
Unit cost & $\$ 15.67$ \\
Sales price & $(\$ 19-\$ 15.67)$ & $\$ 19$ \\
Gross margin & & $\mathbf{R ~ 5 7 2}$ \\
\hline & $(\$ 6.451 .500 / 400.000)$ & 400.000 \\
\hline Number of units & $\$ 16.13$ \\
Unit cost & $(\$ 20-\$ 16.13)$ & $\$ 20$ \\
Sales price & & $\$ 3.87$ \\
Gross margin & & \\
\hline
\end{tabular}

\section{Ha4: Mengetahui yang harus dilakukan manajer perusahaan untuk menghindari kegagalan dalam implementasi sistem baru}

Dalam implementasi sistem baru pada suatu perushaan yaitu sistem Activity Based Costing, factor perilaku dan organisasional mempunyai peran penting dimana harus adanya komunikasi antar departemen yaitu manajemen akuntansi, manajer produksi, dan manaejer operasional. Faktor dari perilaku manusia yang mempengaruhi implementasi sistem Activity Based Costing dapat digolongkan menjadi 7 variabel yaitu :

1. Dukungan manajemen puncvak terhadap sistem Activity Based Costing

2. Keterkaitan Activity Based Costing dan sistem manajemen biaya untuk mengevaluasi kinerja dan kompensasi

3. Keterkaitan Activity Based Costing dan sistem manajemen biaya dengan strategi persaingan yaitu mencakup strategi :
a. Mutu
b. Kecepatan 
c. akurat

4. Kecukupan sumber - sumber internal untuk implementasi sistem Activity Based Costing

5. Pelatihan dalam pendesainan, pengimplemantasian dan penggunaan sistem Activity Based Costing dan sistem manajemen biaya

6. Pemakaian informasi non akuntansi dalam sistem manajemen biaya

7. Konsesus mengenai tujuan sistem manajemen biaya

Strategi - strategi Activity Based Costing seharusnya memusatkan pada variable - variable manusia dan organisasi karena masing - masing variable tersebut bermanfaat untuk membantu perusahaan dalam mengidentifikasikan pengimplementasi dari penggunaan sistem Activity Based Costing beserta strategi - strategi nya agar sukses. Dalam hal pencapaian suskes tersebut, yang harus dihindari pengguna sistem tersebut adalah kegagalan dalam implementasinya.

Ada 6 cara untuk menghindari kegagalan dalam implementasi sistem Activity Based Costing sebagai berikut

1. Melibatkan manajemen dan para karyawan dalam menciptakan sistem Activity Based Costing

2. Mempertahankan sistem secara parallel

3. Menggunakan Activity Based Costing pada pekerjaan yang akan menyebabkan kesuksesan

4. Mempertahankan desain awal Activity Based Costing yang sederhana

5. Menciptakan insentif yang diharapkan

6. Mendidik manajemen tentang Activity Based Costing

Dalam menghindari kegagalan dalam implementasi sistem Activity Based Costing, perusahaan juga dapat mengetahui dengan jelas kapan saat yang tepat untuk penggunaannya yang dapat dilihat pada beberapa hal, yaitu :

1. Pada saat biaya overhead tinggi

2. Mempunyai produk berbeda, kompleksitas, volume, jumlah tenaga kerja langsung

3. Biaya kegagalan produk yang tinggi 


\section{Ha5: Mengetahui dasar pertimbangan manajer perusahaan dalam implementasi sistem baru yaitu Activity Based Costing}

Dalam lingkungan manufaktur setidaknya ada 3 faktor yang menyebabkan sistem biaya konvensional tidak mampu membebankan biaya overhead pabrik secara teliti pada produk (Supriyono, 1998 :281), faktor - faktor tersebut adalah sebagai berikut :

1. Perusahaan menghasilkan beberapa jenis produk

Ketepatan pembebanan biaya overhead pabrik pada produk tidak menimbulkan masalah jika perusahaan hanya menghasilkan satu jenis produk. Tetapi jika menghasilkan beberapa jenis produk dengan menggunakan fasilitas yang sama maka biaya overhead pabrik merupakan biaya bersama untuk seluruh produk yang dihasilkan. Kondisi ini mengharuskan manajemen untuk mengidentifikasikan jumlah biaya overhead pabrik yang ditimbulkan oelh masing-masing jenis produk

2. Biaya overhead pabrik berlevel non unit jumlahnya besar

Sistem biaya konvensional dengan mendasarkan tarif tunggal biaya overhead pabrik dan tarif departemen biaya overhead pabrik hanya cocok jika sebagian besar biaya overhead pabrik di dominasi oleh biaya overhead pabrik berlevel unit. Dalam lingkungan manufaktur maju pada umumnya biaya overhead pabrik berlevel non unit jumlahnya besar sehingga pemakaian sistem konvensional untuk kondisi ini menimbulkan distorsi biaya

3. Diversitas produk lebih tinggi

Biaya berlevel non unit yang berjumlah besar belum tentu mengakibatkan sistem biaya konvensional menimbulkan distorsi.

\section{SIMPULAN}

Dari hasil Analisa dan pembahasan sebelumnya, maka dapat di ambil beberapa kesimpulan sebagai berikut : 
1. Perhitungan biaya produk per unit dengan sistem konvensional yang dilakukan oleh perusahaan melalui 2 tahap yaitu :

a. Tahap pertama

Biaya overhead pabrik dikumpulkan dalam pusat biaya dari beberapa departemen dengan menggunakan dasar alokasi tertentu

b. Tahap kedua

Biaya overhead pabrik yang melalui tahap pertama di bebankan kepada produk atas dasar jam tenga kerja langsung, jam mesin, atau biaya tenaga kerja langsung

2. Mekanisme perhitungan biaya produk per unit dengan sistem Activity Based Costing terdiri atas beberapa tahap sebagai berikut :
a. Identifikasi aktivitas
b. Menetapkan biaya per aktivitas
c. Menetapkan cost driver
d. Menentukan pool rate
e. Menghitung biaya produk

3. Faktor dari perilaku manusia yang mempengaruhi implementasi sistem Activity Based Costing dapat digolongkan menjadi 7 variabel yaitu :

a. Dukungan manajemen puncak terhadap sistem Activity Based Costing

b. Keterkaitan Activity Based Costing dan sistem manajemen biaya untuk mengevaluasi kinerja dan kompensasi

c. Keterkaitan Activity Based Costing dan sistem manajemen biaya dengan strategi persaingan yaitu mencakup strategi :

- Mutu

- Ketepatan

- akurat

d. Kecukupan sumber - sumber internal untuk dapat implementasi sistem Activity Based Costing

e. Pelatihan dalam pendesainan, pengimplementasian dan penggunaan sistem Activity Based Costing dan sistem manajemen biaya 

f. Pemakaian informasi non akuntansi dalam sistem manajemen biaya
g. Konsensus mengenai tujuan sistem manejeman biaya

4. Terdapat perbedaan antara penggunaan sistem biaya konvensional dengan sistem Activity Based Costing yaitu

a. Sistem Activity Based Costing memfokuskan pada biaya, mutu dan waktu. Sedangkan sistem konvensional berfokus pada kinerja keuangan jangka pendek, contohnya : perhitungan laba

b. Sistem Activity Based Costing dari berbagai pusat biaya sehingga dapat mengukur konsumsi biaya overhead berdasarkan aktivitas batch dan aktivitas fasilitas serta mengalokasikannya ke produk secara akurat. Sedangkan sistem biaya konvensional tidak mampu melakukan hal tersebut

5. Terdapat perbedaan dalam perhitungan biaya produk per unit antara sistem konvensional dengan sistem Activity Based Costing, dimana biaya unit secara konvensional lebih besar sejumlah $\$ 17.26$ untuk produk R 361 dan sistem Activity Based Costing sebesar $\$ 15.67$ yang di karenakan total biaya pada sistem Activity Based Costing lebih kecil sejumlah \$1.640.000. sedangkan untuk produk R 572 secara sistem konvensional lebih kecil $\$ 15.72$ dari sistem Activity Based Costing yaitu \$16.13 ini disebabkan total cost tentang sistem Activity Based Costing lebih besar yaitu 1.287.500

6. Biaya overhead secara konvensional mengalami distorsi terhadap sistem Activity Based Costing, dimana lebih besar yaitu 2.432.520 daripada sistem Activity Based Costing yaitu 1.640.000 untuk produk R 361. Sedangkan untuk produk R 572 secara konvensional, biaya overheadnya sebesar $\$ 1.122 .840$ lebih kecil dari sistem Activity Based Costing yaitu \$1.287.500.

Adapun rekomendasi untuk penelitian ini yang dapat diberikan penulis berdasarkan pembahasan kasus di atas adalah sebagai berikut :

1. Dalam implementasi sistem Activity Based Costing pada suatu perusahaan dapat dilakukan cara - cara sebagai berikut : 
a. Menghubungkan Activity Based Costing dengan strategi, evaluasi kerja, kompensasi dan tujuan Activity Based Costing

b. Menyediakan mekanisme bagi karyawan untuk memahami dan menerima sistem Activity Based Costing

c. Menciptaklan informasi non akuntansi dalam sistem manajemen biaya

2. Perusahaan sebaiknya menerapkan perhitungan biaya produk per unit dengan menggunakan sistem Activity Based Costing dalam kaitannya dengan harga yaitu menentukan dan memberikan harga suatu produk secara wajar kepada konsumen

3. Perusahaan sebaiknay mengevaluasi lebih lanjut aktivitas - aktivitas yang berkaitan dengan proses produksi agar menghasilkan biaya produk yang lebih baik dan lebih akurat

\section{DAFTAR PUSTAKA}

Amin Widjaja Tunggal (2000), Activity Based Costing untuk Manufacturing dan Pemasaran, Edisi revisi, Harvarindo, Jakarta. , Cost Accounting A Managerial Emphasis, 10 th Edition Prentice Hall International, Inc, Upper Saddle River, new Jersy.

Baldic siregar dkk (2011), akunatsni Biaya Edisi 2, Penerbit Salemba

Daljono (2011), Akuntansi Biaya, Badan Penerbit Universitas Diponegoro, Semarang.

Henry Simamora (1999), Akuntansi Manajemen, cetakan pertama, salemba Empat, Jakarta. , Akuntansi Biaya pengumpulan Biaya dan Penetuan Harga Pokok Buku I, Edisi kedua, BPFE, Yogyakarta.

Kusnadi HMA, Zainyl Arifin, Moh. Syadeli (2001), Akuntansi Manajeme (Komprehensif, Traditional dan kotemporer), Universitas Brawijaya, Malang.

RA. Supriyono (1999), manajemen Biaya : Suatu Reformasi Pengelolaan Bisnis, Edisi pertama, BPFE, Yogayakarta.

William K Carter (2001), Cost Accounting, Penerbit Salemba, Buku 1 Edisi 14. 